\title{
What drives the urban water regime? An analysis of water governance arrangements in Hyderabad, India
}

\author{
Marvam Nastar $^{1}$
}

\begin{abstract}
Urban water scarcity is increasingly seen as a governance issue, not least in cities like Hyderabad, India, where the demand for urban water exceeds the available supply to the extent that some low priority areas in the city receive water for only a few hours on alternate days. Based on a multi-level perspective in transition studies, this study explores the major interplay between actors in the urban water regime and analyzes how that influences access to water among the urban poor. The findings show how the practices of the consolidated regime are environmentally, socially, and economically unsustainable. In investigating the driving forces behind the attributes of the urban water regime, we draw attention to the impact of landscape pressures, i.e., international donors' influence on water policy, and initiatives at the regime and niche levels. Further, and in response to that, we investigate potential niche experiments promoting water access for the urban poor. Accordingly, it is suggested that socio-technical and socio-political "niche" experiments could be combined into a citizen-based challenge against the existing urban regime practices and the dominant discourses at the landscape level. Here water harvesting techniques could be a viable niche innovation with citizen involvement to be scaled-up in an enabling institutional setting. This requires a coalition of social movement and political action, providing an arena for a new vision in the water sector that would replace the one imposed by landscape forces represented by international donors.
\end{abstract}

Key Words: Hyderabad; India; multi-level perspective; transition studies; water governance

\section{INTRODUCTION}

Inadequate access to improved water has been a persistent challenge for many Indian cities, where residents have to cope with daily shortages (The Times of India 2013). As of 2010 more than 50 percent of approximately 400 million Indian city dwellers have no access to water pipe connections located inside the household plot or yard (JMP 2013). If one considers service quality (e.g., continuity, portability, and purity) or cost of supply, the statistics are even less promising for a great number of city dwellers, who currently constitute one third of India's approximate 1.2 billion inhabitants (JMP 2013).

In an attempt to increase the efficiency in public service provision in urban areas, the Ministry of Urban Development (MoUD) promoted a series of institutional, fiscal, and financial reforms under the 74th Constitutional Amendment Act ( $74^{\text {th }}$ CAA) of 1992, which aimed to strengthen municipal level governance (MoUD 2012, Ruet and Lama-Rewal 2012). The Act provides a basis for state governments to delegate responsibility for providing electricity and water services to urban bodies, and thus make federal and state government more responsive. The $74^{\text {th }}$ CAA is targeted towards the implementation of a decentralized and self-sufficient governance system, and is considered to be a means to ensure local cultural and political autonomy by diffusing social and political tensions at different scales and levels of government (MoUD 2012, Ruet and Lama-Rewal 2012). The challenges of implementing decentralization in water service delivery, however, have been enormous. The maintenance of central control through regulation and funding by the federal and state governments, the inadequate capacity to perform decentralized functions effectively by local governance, and the continued exclusion of the poor from influence over the decisions affecting their welfare, are among the main obstacles and issues associated with decentralization and institutional changes implemented by the $74^{\text {th }}$ CAA (Bardhan 2002, Crook 2003, Wilder and Romero Lankao 2006, Greig et al. 2007, Joshi 2007). But what are the main driving forces causing these barriers?
Furthermore, who are the actors involved in the process of implementation, and what motivates their actions?

The dynamics of changes in urban water governance in Hyderabad, India are analyzed by using a multi-level perspective (MLP) from transition studies. MLP is used to analyze the attributes of the urban water regime, and their impacts on water services as well as to generate useful material on the interplay among actors at different levels and how that interaction shapes current urban water governance practices. While the usefulness of the MLP has been illustrated by several case studies analyzing societal changes in the water domain (van der Brugge et al. 2005, Pahl-Wostl 2007, van der Brugge and Rotmans 2007, Holtz et al. 2008, Brown et al. 2009, van de Meene and Brown 2009), it has also been widely criticized (Geels 2011). Thus, this study draws attention to debates on the conceptualization and application of the regime and aims to delineate the concept empirically.

Unlike previous research studies, often carried out in western societies and with a focus on socio-technological regimes, we pay particular attention to socio-political aspects of the regime, as exemplified by the case of the urban water regime in Hyderabad. In doing so, insights from political economy and political ecology are employed, and the politics behind governance arrangements are discussed, as well as the way in which these affect water allocation and distribution in cities (Loftus and McDonald 2001, Castro 2004, Heynen et al. 2006, Bakker 2010). Such insights and perspectives often throw light on the political and economic processes at the landscape level that in turn shape and reshape water policies manifested at the regime level. Furthermore, reflections on opportunities for regime change in relation to the attributes of the urban water regime in Hyderabad are provided.

\section{METHODOLOGY}

The analytical framework for the study of the urban water regime in Hyderabad in connection with the $74^{\text {th }}$ CAA institutional reforms was drawn from a review of the literature on multi-level 
perspectives in transition studies. The application of MLP, as well as criticisms of it, were informed by the recent academic publications on MLP (Geels 2002, Berkhout et al. 2004, Smith et al. 2005, van der Brugge and Rotmans 2007, Genus and Coles 2008, Geels 2010, Shove and Walker 2010, Geels 2011, Meadowcroft 2011, van den Bergh et al. 2011, Lawhon and Murphy 2012).

The analysis starts around 1992, when the $74^{\text {th }}$ CAA was enacted to bring about administrative and political decentralization in the urban context in general and in urban water institutions in particular (Ruet and Lama-Rewal 2012). In examining the attributes of the urban water regime, through detailed document analysis, I first traced institutional change in terms of organizational reforms, policy change, and legislative change and identified the particulars of the water governance arrangements. I then reviewed policy documents on water resources and urban development ministries, as well as regional and local government reports (MoWR 2002, JNNURM 2005, National Water Commission 2005, GHMC 2006, JNNURM 2006, MoWR $2012 b$ ). Furthermore, I traced developments in the water sector and combined an analysis of other document types, such as memoranda, minutes of meetings, press releases, program proposals, and articles in scientific journals.

In investigating the quality of water services in Hyderabad, I used and constructed a variety of data from official government reports, newspapers, and scientific journal articles on the assessment of water provision. The data were extracted from different chapters of city development plans provided by the municipality as part of an appraisal of the national urban renewal mission (JNNURM 2005, GHMC 2006, JNNURM 2006). In addition, I extracted a data set on the quality of water access from existing scientific journal papers and field studies. One of the main sources of data was the Hyderabad field study by Raghavendra (2006) on how water is accessed by households in different parts of the city. The sample size of the field study was 550 households, from which $60 \%$ of respondents resided in the city core, and $40 \%$ were chosen from peri-urban neighborhoods (Raghavendra 2006). Another important source of data on different modes of water services and payment schemes was the survey by Davis et al. (2008) in 14 "notified" "[1] slum areas comprising 200-1000 households. The sample size was 919 households in total, with the median length of an interview being 45 minutes (Davis et al. 2008). While the government reports evaluated the overall performance of the municipality and water utilities, these assessments were not always consistent with newspaper reports or scholarly publications. Hence, I compared and contrasted these data with primary data on modes of access and payment schemes.

In January 2011, I conducted two weeks of intensive fieldwork in disadvantaged urban areas of Hyderabad and carried out 15 indepth interviews with residents of the three slum areas of Jagadgirigutta in Quthbullahpur, Fathenagar in Kukatpall, and Secunderabad Division in Begumpet towns. The areas were selected based on my familiarity with the city neighborhoods through other research studies. Interviews were conducted based on the residents' availability and willingness to discuss waterrelated issues. All the interviews were conducted in a structured open-ended format through a translator who was fluent in Telegu, Hindi, and English. Narrative walks, in which people share their knowledge and experiences with the researcher in a storytelling style, were also used to enable the triangulation of data from interviews, documents, and in situ observation (Jerneck and Olsson 2013). The data analysis was based on information about water connectivity, sufficiency of supply, water filtering devices, water pressure, frequency of water availability, and affordability of price, as well as the incidence of water-related diseases and predicaments in the household.

\section{ANALYTICAL FRAMEWORK}

\section{A multi-level perspective from transition studies}

The field of transition studies has emerged over recent decades as a systematic approach to address the complexity of sustainability issues in functional domains like water, food, energy, etc. (van den Bergh et al. 2011). The MLP framework in transition studies is an analytical tool used to understand a wide range of historical and hypothetical/future processes of change in a given socio-technological system (Geels 2010, 2011). The dynamics of such systems are characterized by complex and longterm changes in technology, culture, policies, politics, power, and economics, in which a wide range of vested interests are involved to promote particular solutions, policy instruments, or packages (Geels 2010, 2011, Meadowcroft 2011, van den Bergh et al. 2011).

Considering the complexity and multi-faceted characteristics of urban water regimes, the application of MLP is useful, first in terms of providing a frame for discussion of differences in perception, ambition, and understanding of transition objectives as normative goals, and for systematically orienting these aspirations towards real efforts (Meadowcroft 2011). Second, the MLP framework is flexible, meaning that different theories and concepts can be combined to explore the intricacy of interactions among critical components of a water governance system, i.e., water legislation, policies and reforms, civil society, policy makers and water organizations (Geels 2010). Hence, a comprehensive understanding of the process of societal change can be generated and used further to assess water governance practices. Third, the transition framework offers a practical toolbox of techniques to choose from in order to scale up successful experiments to achieve the governance objectives (Rotmans and Loorbach 2009).

A MLP comprises three analytical levels: landscape, regime, and niche. The landscape level acts as an overall structure in which regimes and niches interact with each other. Change at this level is relatively slow and corresponds to broad societal trends (Geels 2002, van der Brugge et al. 2005). The landscape level, as an "external context", includes the "technical and material backdrop that sustains society" as well as "demographical trends, political ideologies, societal values, and macro-economic patterns" (Geels 2011:28). Therefore, landscape pressures can be identified as climate change, population dynamics, Millennium Development Goals, as well as economic and political agendas behind development in the water domain. International organizations such as the World Bank (WB) and the International Monetary Fund (IMF) shape dominant economic and political discourses at this level, which in turn influence the policies and programs of water institutions in India at the regime and niche level.

Geels (2011:31) defines the regime as an "interpretive analytical concept" referring to the "deep structure" and stability of an existing system, consisting of a set of institutional settings that 
support and reinforce predominant technology, politics, markets, user preferences, legislation, or social conventions (Foxon 2002, Geels 2002, van der Brugge et al. 2005, Geels 2011). In this study, the concept of urban water governance broadly corresponds with this definition of regime. The niche level can be described as the experiments and projects formed by a small group of agents that deviate from the regime; these experiments can be scaled up by different means such as technological innovations or through various types of social mobilizations (Geels 2010, Loorbach 2010).

In changing regimes, one of the dominant transition pathways, among others (e.g., transformation, reconfiguration, technological substitution, dealignment/realignment) is facilitated by the transition management cycle (Rotmans and Loorbach 2009, Geels 2011). At the center of this bottom-up model of change, lies the importance of building a protected space for niche experiments, in which actors use social learning processes to acquire knowledge, leading to a new perspective on a transition issue, thus challenging regime practices (Rotmans and Loorbach 2009, Geels 2011). Here, it is hypothesized that actively communicating the shared vision and transition pathways into other networks will encourage people to join the innovation network and thus build joint strategic agendas (Rotmans and Loorbach 2009, Geels 2011). In a sense, the outcome of the protected space can likewise stimulate the formation of new coalitions and networks to scale up potential niche experiments.

\section{Criticisms of MLP and ongoing debates}

MLP has been the subject of various types of criticisms that have been acknowledged and addressed at length in the recent literature on MLP (cf. Geels 2010, 2011). Some of the critiques have led to essential contributions that expand and improve the framework (van den Bergh et al. 2011). For example, several scholars have drawn attention to the conceptualization and application of power dynamics in MLP, between and within levels (Smith et al. 2005, Avelino and Rotmans 2009, 2011, Lawhon and Murphy 2012). Others have highlighted the importance of multirelational interactions and 'flat ontology' at each level (Shove and Walker 2010). They have argued that the "nested hierarchy" concept misses out on the importance of local practices, whose horizontal/ flat circulation can be the trigger for transition (versus vertical/ hierarchical niche-regime interaction). As acknowledged by Geels (2011), this argument indicates that one should not only look at the niche networks beneath the regime level to understand how niches scale up, or how the regime reproduces itself; it is equally important to scrutinize the interaction within a network of heterogeneous niches and how they communicate with each other. This considered, the interactions between sociotechnological and socio-political niche experiments at the micro level will be scrutinized.

Another important relevant critique is related to the ambiguity of the regime concept and its application to empirical cases (Berkhout et al. 2004, Genus and Coles 2008, Markard and Truffer 2008). Criticisms of this aspect often revolve around the problem of drawing boundaries for the regime, both in terms of conceptualization and in terms of application. For example, Genus and Coles (2008) have contended that the MLP framework can only offer a heuristic to organize sets of data, but that it does not offer space for a critical discussion on choices and definitions of niche, regime and landscape levels. As a response, they have offered a constructivist approach, based on actor-network theory, to construct and identify actors, networks, and interactions (Genus and Coles 2008). Furthermore, Markard and Truffer (2008), who argue that the regime concept can be interpreted both as a rule set and as a system, have concluded that the regime should be elaborated and coherently justified before it is applied.

In response, Geels (2011) states that the MLP does not prescribe how broad or narrow the concept of regime should be. Instead, the analyst should articulate the concept based on the object of analysis. Therefore, what constitutes a regime depends on the subject matter and theories utilized to investigate it. In an attempt to delineate the concept of regime in connection with water management analyses, Holtz et al. (2008) describe different characteristics of a regime, such as the autonomy, coherence, heterogeneity, purposefulness, and stability of actors. These attributes, in sum, indicate that regimes are autonomous and stable societal systems that serve one or several societal functions, which bear on human needs while comprising multiple and heterogeneous actors (Holtz et al. 2008). Inspired by the considerations of new institutionalism, some researchers have contributed to the delineation of urban water regimes by focusing on technological aspects of water organizations as well as regulations, norms, and values embedded in the management of water resources and services (Pahl-Wostl et al. 2007, Brown et al. 2009).

\section{THE URBAN WATER REGIME IN HYDERABAD}

Currently, the water coverage in Hyderabad as a percentage of the total population of the city is reported to be $95 \%{ }^{[2]}$ (GHMC 2006, Water and Sanitation Program 2008) and 90\% in slum areas (GHMC 2006). In spite of these figures, water access is intermittent, and in low-income areas, water is supplied for just a few hours on alternate days (George et al. 2009, McKenzie and Ray 2009). The insufficient water access and delivery has resulted in many health issues such as gastroenteritis, dysentery, liver enlargement, malnutrition, ringworm, scabies, and other skin diseases (McKenzie and Ray 2009). In addressing these issues, the urban water regime in Hyderabad has gone through many changes at different scales and levels. In Table 1, the current actors constituting the structure of the urban water regime are listed. This comprises the Ministry of Water Resources and the Ministry of Urban Development at the federal level and constitutional bodies at the state (Andhra Pradesh) level.

\section{The legislative aspect}

The first National Water Policy (NWP) in India was adopted in 1987 and updated in 2002 and 2012 by the Ministry of Water Resources (MoWR 2002, 2012b). The main policy changes have been in relation to the prioritization of water uses, starting with drinking water, and followed by irrigation, hydropower, ecology, agro-industries and other sectors (MoWR 2002, 2012b). Furthermore, in India's national water policies, water is treated as "a prime natural resource, a basic human need and a precious national asset" (MoWR 2002:1), as well as an "economic good, so as to promote its conservation and efficient use" (MMR 2012b:6). In none of the policies since 1987 is the right to water protected, despite the fact that India was among the countries voting for the United Nations General Assembly Resolution $64 / 292$ in 2010, which recognized access to clean water and 
Table 1. Regime actors at different administrative and political levels in relation to urban water governance in Hyderabad, Andhra Pradesh, India. Sources: Greater Hyderabad Municipal Corporation 2006, Hyderabad Metropolitan Development Authority 2010, Ministry of Urban Development 2012, Ministry of Water Resources $2012 a$.

\begin{tabular}{|c|c|c|}
\hline & Organization & Responsibilities (included but not limited to) \\
\hline Federal Level & $\begin{array}{l}\text { Ministry of Water Resources } \\
\text { Ministry of Urban Development }\end{array}$ & $\begin{array}{l}\text { Initiation of the National Water Policy of } 1987,2002 \text { and } 2012 \\
\text { Initiation of the National Urban Policy including the 74th } \\
\text { Constitutional Amendment Act of } 1992\end{array}$ \\
\hline State (AP) Level & $\begin{array}{l}\text { Hyderabad Metropolitan } \\
\text { Development Authority (HMDA) } \\
\text { Water Supply and Sewerage Board } \\
\text { (HMWSSB) } \\
\text { Greater Hyderabad Municipal } \\
\text { Corporation (GHMC), earlier known } \\
\text { as MCH }\end{array}$ & $\begin{array}{l}\text { Supervision of developmental projects in the Hyderabad } \\
\text { Metropolitan Region and coordination of activities among local } \\
\text { bodies, i.e., HMWSSB, GHMC, etc. } \\
\text { Provision and maintenance of water supply and sewerage facilities } \\
\text { in Hyderabad and surrounding municipalities } \\
\text { Preparation of City Development Plan (CDP) and City's } \\
\text { infrastructure provision }\end{array}$ \\
\hline
\end{tabular}

sanitation as a human right (United Nations General Assembly 2010).

Following the idea of decentralization and the enactment of the $74^{\text {th }}$ CAA, both MoUD and MoWR encourage private sector participation in water provision, specifically under the publicprivate-partnership (PPP) model in water service delivery in urban areas (Ministry of Water Resources 2002, Ministry of Urban Development 2012, Ministry of Water Resources 2002, 2012b). In fact, the federal government of India is in the process of preparing "a model legislation for facilitating private sector participation in urban infrastructure" (MoUD 2012).

\section{The managerial aspect}

The Hyderabad Metropolitan Water Supply and Sewerage Board (HMWSSB) is responsible for the supply of potable water, including planning, design, construction, maintenance, operation, and management of the water supply system, as well as sewerage disposal and treatment (HMWSSB 2008). Considered an example of successful reforms in water provision, and in line with the $74^{\text {th }}$ CAA, HMWSSB was given semiautonomous status by a board of directors after receiving a US\$89 million loan from the World Bank in 1990 (HMWSSB 2008). The HMWSSB works in coordination with the Greater Hyderabad Municipal Corporation (GHMC), which is in charge of installing and maintaining public city infrastructure including water and sewer networks (GHMC 2011). As an urban local body, the GHMC is responsible in particular for the improvement of water services in low-income areas including slums.

In order to improve access to water services, the HMWSSB implemented several organizational reforms and initiatives like Metro Customer Care (MCC), Single Window Cell (SWC) and Metro Water's Citizen's Charter to empower citizens (Caseley 2006). The MCC's task was to register citizens' complaints concerning corruption, lack of transparency, weak accountability for service delivery, and long delays, and the SWC's task was to receive, process, and coordinate all new water and sewerage connection applications (Caseley 2006). The purpose of the Metro Water's Charter's task was to set performance standards by outlining measurable service delivery norms for a range of services, including citizens' obligations, such as paying bills on time, and reporting illegal activity (McKenzie and Ray 2009).
Regarding the impacts of the organizational reforms at HMWSSB, Robinson (2007) points out that improvement in the technical capacity of the HMWSSB staff and their involvement in designing a more customer-oriented approach has enhanced water service delivery in Hyderabad (Robinson 2007). In other studies, Davis et al. (2008) and Caseley (2006) draw attention to the effectiveness of the SWC initiative in reducing the time and cost for customers applying for new water and sewer connections (Caseley 2006, Davis et al. 2008). In addition, they highlight how MCC has improved the provision for dealing with complaints (Caseley 2006, Davis et al. 2008).

Although these initiatives have increased the ability of users to interact with the HMWSSB effectively, they are too focused on registered consumers (Joshi 2007). This excludes the urban poor in slum areas who are neither recorded consumers nor are served by providers. In fact, there is little evidence to suggest that urban dwellers have benefited from HMWSSB's reforms, as compared with middle and upper class households that probably have a higher literacy rate and internet access, which enables them to benefit from computerized systems and new reforms.

\section{The technical aspect}

In the early stages of urban development, the provision of water is generally based on local groundwater resources and the diversion of water from lakes, ponds, rivers, and tanks (Lundqvist et al. 2003, Mukherjee et al. 2010). This was also the case in Hyderabad, which eventually had to look to long-distance transfer of water from beyond the city limits and boundaries because, as shown in Table 2, the local water resources were exhausted.

As the table indicates, the distance from the water sources to Hyderabad has increased over the years due to the insufficiency of nearby sources to quench the urban thirst. The greater the distance, the higher the cost of water provision. As examples, the cost of one kiloliter of Krishna bulk water (at a distance of 120 $\mathrm{km}$ ) is five times greater than the cost of Osman Sagar and Himayath Sagar bulk water at less than $15 \mathrm{~km}$ (George et al. 2009). In addition, the drop in groundwater in the city may worsen as a result of increased runoff and reduced infiltration as the built-up areas rapidly expand (Van Rooijen et al. 2005, George et al. 2009). 
Table 2. Hyderabad water supply resources. Sources: Van Rooijen et al. 2005, Greater Hyderabad Municipal Corporation 2006b, Hyderabad Metropolitan Water Supply and Sewerage Board 2008b, George et al. 2009.

\begin{tabular}{|c|c|c|c|c|}
\hline Water resource & Year of Commission ${ }^{\dagger}$ & Impoundment name & River & $\begin{array}{l}\text { Distance from the } \\
\text { city }(\mathrm{km})\end{array}$ \\
\hline Osman Sagar & 1920 & Osmansagar & Musi & 15 \\
\hline Himayat Sagar & 1927 & Himayatsagar & Esi & 9.6 \\
\hline Manjira Phase - I \& II & $1965 \& 1981$ & Manjira Barrage & Manjira & 58 \\
\hline Manjira Phase - III \& IV & $1991 \& 1994$ & Singur Dam & Manjira & 80 \\
\hline Krishna Phase - I \& II \& III & $2002 \& 2006 \& 2011$ & Nagarjuna Sagar Reservoir & Krishna & 120 \\
\hline Sripada Sagar & 2011 & Sripada Sagar Reservoir & Godavari & Approx. 200 \\
\hline
\end{tabular}

${ }^{\dagger}$ The year of commission is different from the sanction date when funding for the projects was approved and released. For example, the commission year of the Krishna Phase II project is documented as 2006, while the project was sanctioned in November 2007.

\section{The social aspect}

While water reforms and policy claim to be pro-poor, they do not adequately address access to water for the urban poor. For example, in India $70-80 \%$ of the subsidies spent on water services do not reach the poor. This is so firstly because they do not have metered connections to the water distribution system (Whittington 1992, Rakodi 2000, Foster et al. 2002, Whittington 2003, Water and Sanitation Program 2008). Of the $90 \%$ with household connections in Hyderabad, only roughly $40 \%$ of the meters work properly (Whittington 2003, GHMC 2006). In slum areas, where dwellers have no access to the water network, the situation is even worse, as poor households rely on tankers or cart vendors charging two to 20 times more per liter of water as compared to households with a regular water network connection (Davis et al. 2008). This is in line with other studies indicating that water reforms and policy have little impact on the urban poor in terms of better access to water at an affordable price (Robbins 2003, Raghavendra 2006, Greig et al. 2007, Bakker et al. 2008, Davis et al. 2008, Baindur and Kamath 2009).

Secondly, in low-income areas the water connection is often shared among a group of households, making the water bills much higher than single household usage since the calculation is made on the basis of increasing block tariff (HMWSSB 2008). In more than $90 \%$ of the cases, water consumption among users with private metered connections (mainly middle and upper class) falls under the first couple of blocks of the water tariff (up to 30 kiloliters per month) where water is highly subsidized and relatively cheap, at less than $12 \mathrm{Rs}$ per kilo-liter (Whittington 2003, Raghavendra 2006, HMWSSB 2008). On the other hand, users sharing only one connection end up paying more per kiloliter since higher blocks of the water tariff are not subsidized creating a situation where individual users in low-income areas pay more for water while receiving less (Whittington 2003, Raghavendra 2006, HMWSSB 2008).

To sum up the attributes of the urban water regime in Hyderabad, India, from 1992 to the present, one could argue that it follows the ideology of water as an economic good in line with the Dublin Principles, in which the idea of public-private partnership paves the way towards privatization of water services. In fact, privatization of water service delivery has already started in Delhi
(The Times of India 2011, 2012). As in many other developing countries, the urban water regime is dominated by technocrats who promote long-distance transfer of water to secure city development without considering environmental damage, impacts on the agriculture sector, etc. (MoWR 2012a). From a distributional perspective, there is an apparent inequality in access to water services. While high and middle income earners benefit from the organizational reforms in water service delivery and have access to improved services, urban low-income earners are to a great extent excluded. This is far from fulfilling the objectives of the water initiatives and the pro-poor policy.

\section{DISCUSSION}

In understanding the driving forces behind the above attributes of the regime, and how they can be influenced to provide the urban poor with better water access, Geels (2011) highlights the role of landscape pressures on the regime as well as their influence on niche experiments.

\section{Landscape pressures on the regime}

In the case of organizational reforms in the water service delivery sector in Hyderabad, in which the urban poor have barely benefited from the outcome, political considerations at the landscape level have played a major role. In 1998, the government of Andhra Pradesh and HMWSSB were on the verge of securing a second loan (US $\$ 300$ million) from the World Bank (WB) to invest in improving the existing infrastructure for water and sanitation services in Hyderabad. With a sudden turnaround in May 1998, both the WB and the International Monetary Fund (IMF) suspended their ongoing programs and funds in India, including those projects related to water infrastructure investments, because of the Indian government's decision to conduct a nuclear test (Caseley 2006). The HMWSSB therefore had to change direction from improving water service delivery objectives through investment in infrastructure. They were instead left with no choice but to focus on enhancing service delivery through increasing its staff's technical capacity and designing consumer-oriented approaches, since it was a relatively cheaper and faster strategy, in terms of the impact on water service delivery, than investments in water infrastructure (Caseley 2006).

In relation to the social dimension of the regime, the apparent inequality in water access is also tightly linked with the influence 
of landscape pressures enforced by the actors at this level. For instance, WB loans to the water sector are usually conditional upon spending a significant share of the loan on managerial and other streamlining measures to prepare the groundwork for water privatization, as promoted through the PPP (Swyngedouw 2005, 2006, The Times of India 2011, MoUD 2012). In their report on public and private investment in infrastructure in India, Hall and Lobina (2006) point out that the total investment by the WB and other international donors fell by one third from 1996 to 2002 with the expectation that the private sector would take over (Hall and Lobina 2006). However, the water service delivery sector is one of the least enticing areas for investors in the country because of the fixed capital investment cost in infrastructure and high levels of non-revenue water as a result of the lack of metering, illegal connections, public stand posts and physical losses in the system (Robbins 2003, GHMC 2006, Swyngedouw 2006, McKenzie and Ray 2009). The trend of investment in infrastructure in India indicates that while public investment has declined from 4\% of GDP in 1990 to 3\% of GDP in 1998, private sector investment has increased only marginally from $1.4 \%$ of GDP to $1.6 \%$ (Hall and Lobina 2006). Hence, in order to encourage private sector involvement in the water sector, donor agencies have adopted policies and strategies, such as full-cost recovery mechanisms, to secure capital investment for the firms.

Although full-cost recovery strategies are rational from a corporate viewpoint, the schemes as such might jeopardize the whole idea of boosting water access for the poor in favor of masking high levels of water loss in distribution (Robbins 2003, GHMC 2006, Hall and Lobina 2006, Swyngedouw 2006, McKenzie and Ray 2009). As stated earlier, the urban poor in Hyderabad pay more per drop of water because of the high level of nonrevenue water. The figures for nonrevenue water in the Greater Hyderabad Municipal Corporation (GHMC) and surrounding municipalities are estimated to be $40 \%$ and $60 \%$, respectively (GHMC 2006). Findings from several studies indicate that when water tariff hikes are enforced, households with lower incomes pay higher percentages of their income for water consumption, while middle- and high-income earners pay a very small proportion of their income (Foster et al. 2002, Whittington 2003, Raghavendra 2006, WaterAid 2006, Davis et al. 2008). For example, Water Aid, an Asian Development Bank (ADB) funded $\mathrm{NGO}$, in its assessment of water policy promoted and implemented by $\mathrm{ADB}^{[3]}$ in India, reveals that poorer households are likely to spend $4 \%$ of their income on water consumption while richer households are likely to spend $0.7 \%$ (WaterAid 2006, Kaminsky and Long 2011).

\section{Socio-technological and socio-political niches}

The gradual adjustment of the regime to the slow but prevailing landscape pressures has not only shaped anti-poor, rather than pro-poor, attributes of the urban water regime, but it has also encapsulated potential niche experiments. From a sociotechnological perspective on interaction between niche, regime, and landscape levels, the dominant regime, under the current landscape pressures, tends to narrow the diversity of technological innovations to make them easier and cheaper to deploy (Geels 2002, van den Bergh et al. 2011). In other words, the current regime is willing to adopt technologies that do not require a profound transformation in the established socio-technological infrastructure (Geels 2002, van den Bergh et al. 2011). As in the case of
Hyderabad, the common philosophy of water management is associated with transferring long-distance water to the city and distributing it there by means of pipes and tankers, with at least one third of the water lost during delivery (Van Rooijen et al. 2005). Inaptly, other possible technological innovations in relation to water allocation and distribution to/in the city, like relying on local water resources and rainwater harvesting approaches, have not received enough attention from the water regime. Theoretically, the potential of rainwater harvesting, even in semiarid areas such as Hyderabad (with an annual rainfall level of 700-850 mm), is enormous (Narain 2006). India also has a long tradition of rainwater harvesting systems both in urban and rural areas of the most arid regions of the country (Kumar 2004, Narain 2006). For example, in investigating the future water supply strategies for Hyderabad, George et al. (2009) show that in an average rainfall year in Hyderabad, 80,000 liters of water can be generated from a 100 square meter roof area. This can potentially meet $35 \%$ of the domestic demand annually, as 40 million cubic meters can be collected from the roofs of buildings and stored in rainwater tanks ${ }^{[4]}$ (George et al. 2009).

Nevertheless, water policy and reforms have paid little attention to rainwater harvesting techniques compared to other water supply and delivery strategies, due to pressure from real estate lobbies on the one hand, and the lack of governmental incentives on the other (Chakrabarti 2001, Kumar 2004, Narain 2006). For example, rainwater harvesting is an optional nonmandatory reform under the urban renewal plans in Hyderabad, and the government has withdrawn the $50 \%$ subsidy on structures related to the Hyderabad rainwater harvesting "Neeru-Meeru" (Water and You) initiative (HMWSSB 2008, JNNURM 2011). In the absence of adequate resources and political will, the ability of urban local bodies to upgrade infrastructure and services has been limited, and in reality, the $74^{\text {th }} \mathrm{CAA}$ has given restricted authority and resources to the local government and civil society to promote investment in other appropriate technologies in the water service delivery sector (Chakrabarti 2001). From a transition perspective, landscape pressures on the regime have not only stabilized regime attributes, but have also made it difficult for niche experiments to be scaled up.

In triggering changes, the transition management cycle highlights the role that actors play in other transition arenas. By drawing attention to the role of "frontrunners", Rotmans and Loorbach (2009) suggest that the enabling conditions for scaling up a novel technology or practice can be made in a virtual network called the transition arena. In this social network arena, actors with particular competencies, creative minds, strategists, and visionaries become a threat to the current regime practices. The outcome of the transition arena can stimulate the formation of new coalitions and networks to challenge the regime practices (Frantzeskaki et al. 2012). Such social networks in Hyderabad could take the form of coalitions within and between land, housing, and water rights activists and disadvantaged households, taking political and social actions, which can lead to the creation of rights to basic citizens' needs (i.e., access to water and sanitation). Social movements in the Global South, e.g., the Phiri water rights case in South Africa (Bond and Dugard 2008) and water protest in Cochabamba in Bolivia (Assies 2003), are examples of these arenas helping to frame discourses on citizen rights and alternatives for future water provision more effectively. 
As stated by Frantzeskaki et al. (2012), the aim of transition arenas is to create narratives and agendas to influence policies. In doing so, critical debates, resistance, disobedience, and political conflict are essential elements for bringing about change and effecting transitions. The history of Andhra Pradesh and Hyderabad is enriched with struggles, including dalits, tribal and women's social movements, for civil, political and economic rights to address the concerns of the people, especially the most vulnerable (CESS 2007). Once the socio-political institutions are in place, it can be expected that innovative niche experiments such as rainwater harvesting (with adequate institutional support) can be scaled up. Otherwise, the niche experiments are more likely to be absorbed by business as usual practices, rather than to improve the situation for the disadvantaged population.

\section{CONCLUSION}

By drawing on debates on the conceptualization and application of the regime, this study has explored legislative, technical, managerial, and social aspects of the urban water regime in Hyderabad, and their impacts on citizens' access to water. It has illustrated that current urban water regime practices are environmentally, socially, and economically unsustainable, especially for the urban poor because of the impact of landscape pressures on both the regime and the niche levels.

Technological approaches in water service delivery confine niche innovations due to landscape pressures and the influential role of the WB and the ADB in designing, promoting, and implementing water policy, urban renewal initiatives, and reforms. Hence, issues related to upscaling niche experiments are necessarily and tightly linked to the lack of protected space resulting from the urban renewal plans and water policy and initiatives. Focusing on bottom-up approaches, this article draws attention to the possibility of building continuous pressure on lock-in regimes through socio-political niche experiments. This process may give frontrunners the protected space that they need to create new coalitions and to engage human capacity to mobilize resources to reach certain goals. It suggests that challenging the regime practices and dominant discourses at the landscape level requires a combination of socio-technical and socio-political niche experiments. Water harvesting techniques could be a viable niche innovation to be scaled up in a suitable and facilitating institutional setting. This in itself requires a coalition of social movements and political action that can create an arena to promote visions of development in the water sector that are different from those imposed by the landscape forces.

Last but definitely not least, much as the role of niche experiments and niche actors is vital in making transition pathways, it is equally important to investigate other landscape pressures, such as climate change, the global economic crisis, or the rise of newly industrializing countries in the Global South as drivers of the world economy that could potentially give the right momentum such that niche experiments could be scaled up. This requires more research on how developments at the landscape level can be changed through regime shifts that occur in broader socioeconomic domains than the water sector alone.

Responses to this article can be read online at: http://www.ecologyandsociety.org/issues/responses. php/6570

\section{Acknowledgments:}

I would like to thank Anne Jerneck as well as anonymous reviewers for their comments on the earlier version of this paper. I also thank Barry Ness and David O'Byrne for proofreading the manuscript. I do also appreciate the support from the Swedish Research Council Formas and the LUCID research school for funding the research done for this paper.

\section{LITERATURE CITED}

Asian Development Bank (ADB). 2003. Water for all: the water policy of the Asian Development Bank. ADB. [online] URL: http:// www.adb.org/documents/water-all-water-policy-asian-development$\underline{\text { bank }}$

Assies, W. 2003. David versus Goliath in Cochabamba: water rights, neoliberalism, and the revival of social protest in Bolivia. Latin American Perspectives 30:14-36.

Avelino, F., and J. Rotmans. 2009. Power in transition: an interdisciplinary framework to study power in relation to structural change. European Journal of Social Theory 12:543-569. http://dx.doi.org/10.1177/1368431009349830

Avelino, F., and J. Rotmans. 2011. A dynamic conceptualization of power for sustainability research. Journal of Cleaner Production 19:796-804. http://dx.doi.org/10.1016/j.jclepro.2010.11.012

Baindur, V., and L. Kamath. 2009. Reengineering urban infrastructure: how the World Bank and Asian Development Bank shape urban infrastructure finance and governance in India. Bank Information Centre, South Asia, New Delhi.

Bakker, K. J. 2010. Privatizing water: governance failure and the world's urban water crisis. Cornell University Press, Ithaca, NY, USA.

Bakker, K., M. Kooy, N. E. Shofiani, and E.-J. Martijn. 2008. Governance failure: rethinking the institutional dimensions of urban water supply to poor households. World Development 36:1891-1915. http://dx.doi.org/10.1016/j.worlddev.2007.09.015

Bardhan, P. 2002. Decentralization of governance and development. Journal of Economic Perspectives 16:185-205. http://dx.doi.org/10.1257/089533002320951037

Berkhout, F., A. Smith, and A. Stirling. 2004. Socio-technical regimes and transition contexts. Pages 48-75 in B. Elzen, F. W. Geels, and K. Green, editors. System innovation and the transition to sustainability: theory, evidence and policy. Edward Elgar, Cheltenham, UK.

Bond, P., and J. Dugard. 2008. Water, human rights and social conflict: South African experiences. Law, Social Justice and Global Development Journal. 2007(1). [online] URL: http://go. warwick.ac.uk/elj/lgd/2008 1/bond dugard/

Brown, R. R., N. Keath, and T. H. F. Wong. 2009. Urban water management in cities: historical, current and future regimes. Water Science \& Technology 59:847-855. http://dx.doi. org/10.2166/wst.2009.029 
Caseley, J. 2006. Multiple accountability relationships and improved service delivery performance in Hyderabad City, Southern India. International Review of Administrative Sciences 72:531-546. http://dx.doi.org/10.1177/0020852306070082

Castro, J. E. 2004. Urban water and the politics of citizenship: the case of the Mexico City Metropolitan Area during the 1980s and 1990s. Environment and Planning A 36:327-346. http://dx.doi. org/10.1068/a35159

Centre for Economic and Social Studies (CESS). 2007. Andhra Pradesh human development report 2007. Government of Andhra Pradesh and CESS, Hyderabad, India.

Chakrabarti, P. G. D. 2001. Urban crisis in India: new initiatives for sustainable cities. Development in Practice 11:260-272. http:// dx.doi.org/10.1080/09614520120056397

Crook, R. C. 2003. Decentralisation and poverty reduction in Africa: the politics of local-central relations. Public Administration and Development 23:77-88. http://dx.doi. org/10.1002/pad.261

Davis, J., G. White, S. Damodaron, and R. Thorsten. 2008. Improving access to water supply and sanitation in urban India: microfinance for water and sanitation infrastructure development. Water Science and Technology 58:887-891. http://dx.doi. org/10.2166/wst.2008.671

Foster, V., S. Pattanayak, and L. S. Prokopy. 2002. Do current water subsidies reach the poor? World Bank, Washington, D. C., USA.

Foxon, T. J. 2002. Technological and institutional 'lock-in' as a barrier to sustainable innovation. Imperial College Centre for Energy Policy and Technology (ICCEPT) Working Paper. Imperial College Centre for Energy Policy and Technology (ICCEPT), London, UK.

Frantzeskaki, N., D. Loorbach, and J. Meadowcroft. 2012. Governing societal transitions to sustainability. International Journal of Sustainable Development 15:19-36. http://dx.doi. org/10.1504/IJSD.2012.044032

Geels, F. W. 2002. Technological transitions as evolutionary reconfiguration processes: a multi-level perspective and a casestudy. Research Policy 31:1257-1274. http://dx.doi.org/10.1016/ $\underline{\mathrm{S} 0048-7333(02) 00062-8}$

Geels, F. W. 2010. Ontologies, socio-technical transitions (to sustainability), and the multi-level perspective. Research Policy 39:495-510. http://dx.doi.org/10.1016/j.respol.2010.01.022

Geels, F. W. 2011. The multi-level perspective on sustainability transitions: responses to seven criticisms. Environmental Innovation and Societal Transitions 1:24-40. http://dx.doi. org/10.1016/j.eist.2011.02.002

Genus, A., and A.-M. Coles. 2008. Rethinking the multi-level perspective of technological transitions. Research Policy 37:1436-1445. http://dx.doi.org/10.1016/j.respol.2008.05.006

George, B. A., H. M. Malano, A. R. Khan, A. Gaur, and B. Davidson. 2009. Urban water supply strategies for Hyderabad, India - future scenarios. Environmental Modeling \& Assessment 14:691-704. http://dx.doi.org/10.1007/s10666-008-9170-6
Greater Hyderabad Municipal Corporation (GHMC). 2006. City development plan. GHMC, Hyderabad, Andhra Pradesh, India. [online] URL: http://www.ghmc.gov.in/downloads/cdpdefault. asp [Accessed 30 March 2011].

Greater Hyderabad Municipal Corporation (GHMC). 2011. Greater Hyderabad Municipal Corporation. [online] URL: http:// www.ghmc.gov.in/index.asp [Accessed 30 March 2011].

Greig, A., D. Hulme, and M. Turner. 2007. Challenging global inequality: development theory and practice in the 21st century. Palgrave Macmillan, New York, USA.

Hall, D., and E. Lobina. 2006. Pipe dreams - The failure of the private sector to invest in water services in developing countries. Public Services International Research Unit, London, UK.

Heynen, N. C., M. Kaika, and E. Swyngedouw. 2006. In the nature of cities: urban political ecology and the politics of urban metabolism. Routledge, New York, USA.

Holtz, G., M. Brugnach, and C. Pahl-Wostl. 2008. Specifying "regime" - A framework for defining and describing regimes in transition research. Technological Forecasting and Social Change 75:623-643. http://dx.doi.org/10.1016/j.techfore.2007.02.010

Hyderabad Metropolitan Development Authority. 2010. Hyderabad Metropolitan Development Authority. [online] URL: http://www.hmda.gov.in/ [Accessed 15 May 2011].

Hyderabad Metropolitan Water Supply and Sewerage Board (HMWSSB). 2008. Hyderabad Metropolitan Water Supply and Sewerage Board. [online] URL: http://www.hyderabadwater.gov. in/wwo/ [Accessed 30 October 2012].

Jawaharlal Nehru National Urban Renewal Mission (JNNURM). 2005. Jawaharlal Nehru National Urban Renewal Mission, overview. Ministry of Urban Employment and Poverty Alleviation, New Delhi, India.

Jawaharlal Nehru National Urban Renewal Mission (JNNURM). 2006. Modified guidelines for projects of Jawaharlal Nehru National Urban Renewal Mission on urban infrastructure \& governance. Ministry Of Urban Development, Government of India, New Delhi, India.

Jawaharlal Nehru National Urban Renewal Mission (JNNURM). 2011. Appraisal of Jawaharlal Nehru National Urban Renewal Mission, final report - Volume I. Ministry of Urban Employment and Poverty Alleviation, New Delhi, India.

Jerneck, A., and L. Olsson. 2013. More than trees! Understanding the agroforestry adoption gap in subsistence agriculture: insights from narrative walks in Kenya. Journal of Rural Studies 32:114-125. http://dx.doi.org/10.1016/j.jrurstud.2013.04.004

Joint Monitoring Programme (JMP). 2013. WHO / UNICEF joint monitoring programme (JMP) for water supply and sanitation. World Health Organization, Geneva, Switzerland; and United Nations Children's Fund (UNICEF), New York, USA.

Joshi, A. 2007. Producing social accountability? The impact of service delivery reforms. IDS Bulletin 38:10-17. http://dx.doi. org/10.1111/j.1759-5436.2007.tb00414.X

Kaminsky, A. P., and R. D. Long, editors. 2011. India today: an encyclopedia of life in the Republic. ABC-CLIO, California, USA. 
Kumar, M. D. 2004. Roof water harvesting for domestic water security: who gains and who loses? Water International 29:43-53. http://dx.doi.org/10.1080/02508060408691747

Lawhon, M., and J. T. Murphy. 2012. Socio-technical regimes and sustainability transitions: insights from political ecology. Progress in Human Geography. 36(3):354-378. http://dx.doi. org/10.1177/0309132511427960

Loftus, A. J., and D. A. McDonald. 2001. Of liquid dreams: a political ecology of water privatization in Buenos Aires. Environment and Urbanization 13:179-199. http://dx.doi. org/10.1177/095624780101300215

Loorbach, D. 2010. Transition management for sustainable development: a prescriptive, complexity-based governance framework. Governance 23:161-183. http://dx.doi.org/10.1111/ j.1468-0491.2009.01471.x

Lundqvist, J., P. Appasamy, and P. Nelliyat. 2003. Dimensions and approaches for Third World city water security. Philosophical Transactions of the Royal Society of London. Series B: Biological Sciences 358:1985-1996. http://dx.doi.org/10.1098/rstb.2003.1382

Markard, J., and B. Truffer. 2008. Technological innovation systems and the multi-level perspective: towards an integrated framework. Research Policy 37:596-615. http://dx.doi.org/10.1016/ j.respol.2008.01.004

McKenzie, D., and I. Ray. 2009. Urban water supply in India: status, reform options and possible lessons. Water Policy 11:442-460. http://dx.doi.org/10.2166/wp.2009.056

Meadowcroft, J. 2011. Engaging with the politics of sustainability transitions. Environmental Innovation and Societal Transitions 1:70-75. http://dx.doi.org/10.1016/j.eist.2011.02.003

Ministry of Urban Development (MoUD). 2012. Urban reforms. [online] URL:http://www.urbanindia.nic.in/urbanscene/urbanreforms/ urbanreform.htm [Accessed 30 August 2012].

Ministry of Water Resources (MoWR). 2002. National water policy 2002. MoWR, Government of India, New Delhi, India.

Ministry of Water Resources (MoWR). 2012a. Domestic water supply. MoWR, Government of India, New Delhi, India.

Ministry of Water Resources (MoWR). 2012b. Draft National Water Policy 2012 as recommended by National Water Board in its 14th meeting held on 7th June, 2012. MoWR, Government of India, New Delhi, India.

Mukherjee, S., Z. Shah, and M. Kumar. 2010. Sustaining urban water supplies in India: increasing role of large reservoirs. Water Resources Management 24:2035-2055. http://dx.doi.org/10.1007/ s11269-009-9537-8

Narain, S. 2006. Community-led alternatives to water management: India case study. Human Development Report Office, United Nations Development Programme (UNDP). [online] URL: http://hdr.undp.org/en/content/community-ledalternatives-water-management-india-case-study

National Water Commission (NWC). 2005. Baseline assessment of water resources. Australian Government, Canberra, Australia.
Pahl-Wostl, C. 2007. Transitions towards adaptive management of water facing climate and global change. Water Resources Management 21:49-62. http://dx.doi.org/10.1007/s11269-006-9040-4

Pahl-Wostl, C., M. Craps, A. Dewulf, E. Mostert, D. Tabara, and T. Taillieu. 2007. Social learning and water resources management. Ecology and Society 12(2). [online] URL: http:// www.ecologyandsociety.org/vol12/iss $2 / \operatorname{art} 5 /$

Raghavendra, S. 2006. Re-examining the 'low water tariff' hypothesis: lessons from Hyderabad, India. Urban Water Journal 3:235-247. http://dx.doi.org/10.1080/15730620601059199

Rakodi, C. 2000. "Getting the pipe laid is one matter and getting the water flowing through the pipe is another": user views on public-sector urban water provision in Zimbabwe, Sri Lanka, Ghana and India. International Planning Studies 5:365-391. http://dx.doi.org/10.1080/713672857

Robbins, P. T. 2003. Transnational corporations and the discourse of water privatization. Journal of International Development 15:1073-1082. http://dx.doi.org/10.1002/jid.1054

Robinson, M. 2007. The politics of successful governance reforms: lessons of design and implementation. Commonwealth \& Comparative Politics 45:521-548. http://dx.doi. org/10.1080/14662040701659944

Rotmans, J., and D. Loorbach. 2009. Complexity and transition management. Journal of Industrial Ecology 13(2):184-196. http:// dx.doi.org/10.1111/j.1530-9290.2009.00116.x

Ruet, J., and S. T. T. Lama-Rewal. 2012. Governing India's metropolises: case studies of four cities. Routledge India, New Delhi, India.

Shove, E., and G. Walker. 2010. Governing transitions in the sustainability of everyday life. Research Policy 39:471-476. http:// dx.doi.org/10.1016/j.respol.2010.01.019

Smith, A., A. Stirling, and F. Berkhout. 2005. The governance of sustainable socio-technical transitions. Research Policy 34:1491-1510. http://dx.doi.org/10.1016/j.respol.2005.07.005

Swyngedouw, E. 2005. Governance innovation and the citizen: the Janus face of governance-beyond-the-state. Urban Studies 42:1991-2006. http://dx.doi.org/10.1080/00420980500279869

Swyngedouw, E. 2006. Power, water and money: exploring the nexus. United Nations Development Programme, New York, USA.

The Times of India. 2011. S Delhi water project on PPP model. The Times of India, [online] URL: http://timesofindia.indiatimes. com/city/delhi/S-Delhi-water-project-on-PPP-model/articleshow/10911593. cms [Accessed 15 August 2011].

The Times of India. 2012. Delhi Jal Board privatization model in deep trouble. The Times of India, [online] URL: http:// timesofindia.indiatimes.com/city/delhi/Delhi-Jal-Board-privatizationmodel-in-deep-trouble/articleshow/15524221.cms [Accessed 15 October 2012]. 
The Times of India. 2013. 22 of India's 32 big cities face water crisis. The Times of India, [online] URL: http://timesofindia. indiatimes.com/india/22-of-Indias-32-big-cities-face-water-crisis/ articleshow/22426076.cms [Accessed 15 September 2013].

United Nations General Assembly. 2010. Recognizing access to clean water, sanitation as human right. Resolution 64/292. United Nation General Assembly, Department of Public Information, News and Media Division, New York, USA. [online] URL: http:// www.un.org/News/Press/docs/2010/ga10967.doc.htm

van de Meene, S. J., and R. R. Brown. 2009. Delving into the "institutional black box": revealing the attributes of sustainable urban water management regimes. Journal of the American Water Resources Association 45:1448-1464. http://dx.doi.org/10.1111/ j.1752-1688.2009.00377.x

van den Bergh, J. C. J. M., B. Truffer, and G. Kallis. 2011. Environmental innovation and societal transitions: introduction and overview. Environmental Innovation and Societal Transitions 1:1-23. http://dx.doi.org/10.1016/j.eist.2011.04.010

van der Brugge, R., J. Rotmans, and D. Loorbach. 2005. The transition in Dutch water management. Regional Environmental Change 5:164-176. http://dx.doi.org/10.1007/s10113-004-0086-7

van der Brugge, R., and J. Rotmans. 2007. Towards transition management of European water resources. Water Resources Management 21:249-267. http://dx.doi.org/10.1007/s11269-006-9052-0

Van Rooijen, D. J., H. Turral, and T. Wade Biggs. 2005. Sponge city: water balance of mega-city water use and wastewater use in Hyderabad, India. Irrigation and Drainage 54:S81-S81. http://dx. doi.org/10.1002/ird.188

WaterAid. 2006. Implementation of ADB's water policy in India: a review. WaterAid India, New Delhi, India.

Water and Sanitation Program (WSP). 2008. Benchmarking urban water utilities in India. WSP-South Asia, World Bank, Washington, D.C., USA.

Whittington, D. 1992. Possible adverse effects of increasing block water tariffs in developing countries. Economic Development and Cultural Change 41:75-87. http://dx.doi.org/10.1086/451996

Whittington, D. 2003. Municipal water pricing and tariff design: a reform agenda for South Asia. Water Policy 5:61-76.

Wilder, M., and P. Romero Lankao. 2006. Paradoxes of decentralization: water reform and social implications in Mexico. World Development 34:1977-1995. http://dx.doi.org/10.1016/j. worlddev.2005.11.026

${ }^{[1]}$ Notified slums are those that are notified by a municipality and other local authorities and are legally entitled to the provision of basic services from the government.

${ }^{[2]}$ In Hyderabad, the method used to estimate water coverage in a given service area is based on the population covered by the network divided by the total population of the area. A more reliable method to estimate water coverage in a service area would be to estimate the number of properties in the service area and the number of properties provided with a direct service connection (Water and Sanitation Program 2008).

[3] "In general, the policy seeks to: promote water as a socially vital economic good that needs increasingly careful management to sustain equitable economic growth and reduce poverty; and advocate a participatory approach in meeting the challenges of water conservation and protection in the region." (Asian Development Bank 2003:13)

[4] With an estimated 500,000 households (composed of four persons with a consumption rate of 50 liters per person per day) in Hyderabad by 2031 (assuming an uptake of 20,000 households per year that will adopt this technology). 